\title{
DEMOGRAPHIC SITUATION OF RURAL POPULATION IN UKRAINE IN THE PERIOD OF INTENSIVE SOCIO-ECONOMIC TRANSFORMATION
}

\author{
Victoria Pantyley ${ }^{1}$
}

Received 27 August 2008; Accepted 16 December 2008

\begin{abstract}
The paper attempts to deal with the problem of the demographic situation of rural population in Ukraine during intensive socio-economic transformations (1990-2007). In the time-spatial depiction there were analysed the following elements of the demographic and socio-economic situation of rural population: changes in population number, birth rate, mortality rate and structure, infant mortality rate, fertility rate, population's age and gender structure, natural increase and migration rate, employment level and structure, unemployment rate, level and structure of income and basic household expenditure, poverty rate, level of satisfaction with one's own material situation. It was found that Ukraine has seen a deep demographic crisis resulting from historical and socio-economic factors. It is also a consequence of the steady impediment and falsification of agricultural reforms.
\end{abstract}

Key words: rural population of Ukraine, socio-economic transformation, demographic crisis.

Streszczenie: Artykuł poświęcony jest demograficznym problemom ludności wiejskiej Ukrainy w okresie intensywnych przemian społeczno-gospodarczych (lata 1990-2007). W artykule przeanalizowano $\mathrm{w}$ ujęciu przestrzenno-czasowym następujące elementy demograficznej i społeczno-gospodarczej sytuacji ludności wiejskiej: zmiany liczby ludności, współczynniki urodzeń, zgonów ludności oraz struktura zgonów, współczynniki umieralności niemowląt, płodności kobiet, struktura ludności według wieku i płci, współczynniki przyrostu naturalnego i migracyjnego, poziom oraz struktura zatrudnienia i bezrobocia ludności, poziom oraz struktura dochodów i wydatków gospodarstw domowych, wskaźniki ubóstwa, a także stopień zadowolenia ludności ze swojej własnej sytuacji materialnej.

Słowa kluczowe: ludność wiejska Ukrainy, przemiany społeczno-gospodarcze, kryzys demograficzny.

\footnotetext{
1 Ph.D. Victoria Pantyley, Department of Economic Geography Marie Curie-Sklodowska University in Lublin, Krasnicka Str., 2, cd 20-817 Lublin, Poland, e-mail: pantyley@yahoo.com
} 


\section{Introduction}

The political reforms, implemented for many years in Ukraine, have caused a number of significant changes noticeable especially in the economy and within the sphere of social relations. The processes are accompanied by a lot of negative social phenomena concerning mainly unemployment, continuing stratification of the society in terms of the level and quality of life, social pathologies, etc. The number of poor people living on the verge of poverty is growing. There arises spatial differences diversification in the course of the conducted reforms which are especially visible between the capital city region already largely benefiting from the changes and agricultural areas in particular. The above mentioned differences result mainly from poor effects of reforming socialist agricultural households.

It should be observed that the contemporary demographic crisis in the rural areas of Ukraine already showed in 1978, when for the first time in the post-war history the population growth rate reached zero, which was the consequence of the proceeding ageing of the society, and the migratory outflow of rural population. "The small demographic explosion" which took place in Ukraine at the end of the $19^{\text {th }}$ and beginning of the $20^{\text {th }}$ century was disrupted by a series of demographic catastrophes caused by World War I and World War II. It was also hindered by the great famine of 1933-1934 as well as by the policy of the former Soviet Union in 1960-70s, directed at the multi-directional development of highly urbanised and industrial areas, which at the same time considerably discriminated rural areas. The great famine in 1933-34 aimed at biological, moral and psychological decimation of farmers in Ukraine brought losses of over $20 \%$ of the population at that time (Zastavnyj 2003). Those who survived had to work on collective farms and to radically change their way of life. World War II losses and post-war repressions prevented the Ukrainian village from being reborn in its traditional form. As a result, the number of rural population in the post-war period was growing very slowly. The years of 1960-70 were not favourable for the development of rural population: the increase in urbanization and industrialization was conducive to the outflow of rural population to cities and to the decrease in the female fertility rate and birth rate. Due to the constant outflow of rural population to cities and the accelerated rate of the population's ageing, the demographic potential of the rural population became exhausted at the beginning of the 70s. The years of 1970-80, known as the "stagnation" years, were quite favourable for the rural population as a result of the increase in its level and quality of life. The total fertility rate of rural women was then 2-3 children per 1 woman of reproductive age, i.e. it was clearly higher than that of women in cities. The transformations of the 90s with their typical drastic decline in living standards, rapid growth in unemployment, lack of social security, rising psycho-social tension caused by the lack of hope for the future - all these side effects undoubtedly worsened the demographic situation and the population's state of health in Ukraine, and especially in its rural areas. Nevertheless, they did not cause the contemporary demographic catastrophe but only deepened the long-lasting demographic crisis, which is a synergistic effect of the interference of historical, social, economic and ecological factors. The author's research subject is the analysis of some parameters of the contemporary demographic situation in Ukrainian rural areas during the political transformation period (1990-2007). The author also analyses the socio-economic factors conditioning this situation.

\section{Demographic changes in rural areas}

\subsection{Changes in the population number}

The natural conditions in Ukraine which favoured high living standards and running different forms of activity, facilitated the development of early settlements yet in prehistoric times. According to estimated data, at the end of $13^{\text {th }}$ century the area of Ukraine was inhabited by 2 mln people, mainly in region of Central Dnieper Basin and Volyn-Halicz Land, while in $17^{\text {th }}$ century the number of Ukrainian population was over $5 \mathrm{mln}$. As a consequence of frequent wars and mass epidemics, the medieval times were not conducive to the rapid development of Ukrainian population. Like in Western European countries, however following a long delay, the number of Ukrainian population began to increase rapidly as late as at the end of $19^{\text {th }}$ century. In the beginning it was around $25 \mathrm{mln}$ people and in 1913 the number reached $32.5 \mathrm{mln}$ (table 1). 
The quick rate of the population growth, observed in XIX century, was hindered by World War I (loss of $2.5 \mathrm{mln}$ people), the revolution in 1917-1920 and the period of "great famine" in 19331934 (c. $10 \mathrm{mln}$ people) (Zastavnyj 2003). World War II and post-war events (famine in 194647) negatively influenced the development of the population, especially its rural part. The population decrease was also the effect of the Soviet authorities' repressions in the western part of Ukraine in 1940-50.

\begin{tabular}{|c|c|c|c|c|c|}
\hline \multirow[t]{2}{*}{ Years } & \multirow{2}{*}{$\begin{array}{c}\text { Total } \\
\text { (in thousands) }\end{array}$} & \multicolumn{2}{|c|}{ Out of total population } & \multicolumn{2}{|c|}{ Population ratio, \% } \\
\hline & & $\begin{array}{c}\text { urban } \\
\text { (in thousands) }\end{array}$ & $\begin{array}{c}\text { rural } \\
\text { (in thousands) }\end{array}$ & urban & rural \\
\hline $\begin{array}{c}1913 \text { within } \\
\text { contemporary } \\
\text { borders }\end{array}$ & 32,510 & 6,790 & 28,420 & 19.3 & 80.7 \\
\hline $\begin{array}{c}1913 \text { within borders } \\
\text { until } 17.09 .1939\end{array}$ & 27,214 & 5,536 & 21,678 & 20.3 & 79.7 \\
\hline $\begin{array}{c}1926 \text { (as 17th } \\
\text { December; within } \\
\text { borders until 17 } \\
\text { September 1939) }\end{array}$ & 29,515 & 5,673 & 23,842 & 19.2 & 80.8 \\
\hline $\begin{array}{l}1937 \text { (as 17th } \\
\text { December) }\end{array}$ & 31,785 & 11,702 & 20,084 & 36.8 & 63.2 \\
\hline $\begin{array}{c}1937 \text { (within } \\
\text { contemporary } \\
\text { borders } 1.01 .1937 \text { ) }\end{array}$ & 40,469 & 13,569 & 26,900 & 33.5 & 66.5 \\
\hline $\begin{array}{l}1959 \text { (as 15th } \\
\text { January) }\end{array}$ & 41,869 & 19,147 & 22,722 & 45.7 & 54.3 \\
\hline $\begin{array}{c}1970 \text { (as } 15 \text { th } \\
\text { January) }\end{array}$ & 47,127 & 25,689 & 21,438 & 54.5 & 45.5 \\
\hline $\begin{array}{l}1979 \text { (as 17th } \\
\text { January) }\end{array}$ & 49,755 & 30,512 & 19,243 & 61.3 & 38.7 \\
\hline $\begin{array}{l}1989 \text { (as 12th } \\
\text { January) }\end{array}$ & 51,707 & 34,588 & 17,119 & 66.9 & 33.1 \\
\hline $\begin{array}{l}2001 \text { (as 5th } \\
\text { December) }\end{array}$ & 48,457 & 32,574 & 15,883 & 67.2 & 32.8 \\
\hline 2007 (as 1st January) & 46,646 & 31,777 & 14,869 & 68.1 & 31.9 \\
\hline
\end{tabular}

Tab 1. Dynamics of population number in Ukraine (in 1913 and results of censuses)

Source: Statystyčnyj ščoričnyk Ukrajiny...2007; Naselennja Ukrajiny...2007.

The situation was also conditioned by the state's policy aimed at the priority development of industrial, highly urbanized areas and clear discrimination of rural areas. As a result, the rural population number constantly decreased, which was noticeable as early as in the $60 \mathrm{~s}$. As to the development of rural population, the years of 1990-2007 were also characterized by negative dynamics. The share of rural population decreased then to $32.7 \%$ in 1990 and to $31.9 \%$ in 2007. In total, the loss of rural population was c. $14 \mathrm{mln}$. of people. It can be explained by the synergic influence of socio-economic factors (decline in the real income of the population, increase in the unemployment level, growth in uncertainty as to one's own and family's future, which was connected with the prolonged transformation period and lack of positive changes in the socio-economic situation of the Ukrainian society) and the influence of ecological factors (the end of the latent period after the Chernobyl disaster). In the territorial aspect, the decrease in the total population number can be observed in the area of the whole of Ukraine. However, the largest decline took place in Chernihiv, Sumy, Kchmelnytskyy, Vinnytsia provinces (fig. 1). 


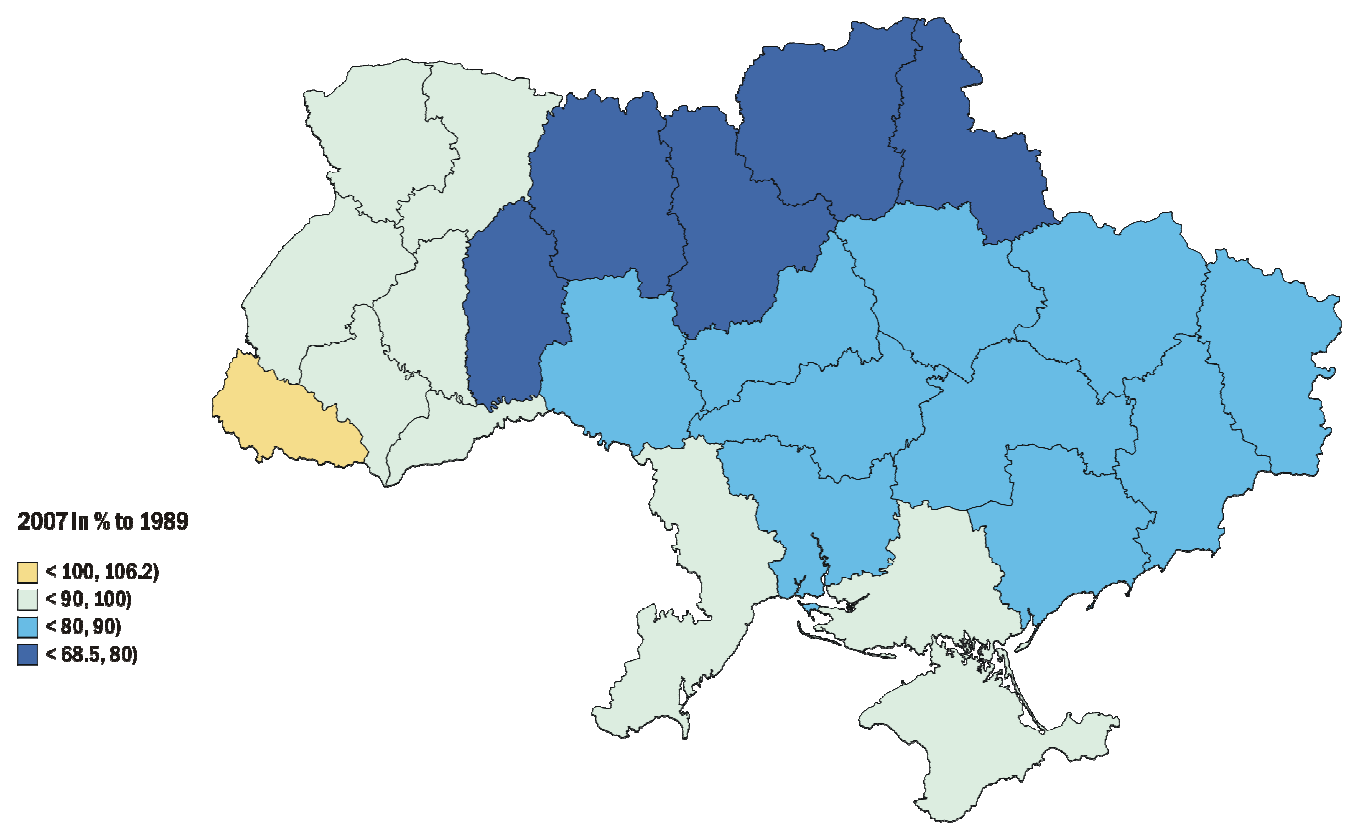

Fig 1. The percentage changes in rural population in 1989-2007 in Ukraine

Source: own elaboration based on the data of Ukraine's State Statistics Committee.

\subsection{Birth rate of rural population}

Lasting since the 70s a systematic and profound drop in the birth rate in Ukraine is a factor directly influencing the very slow rate of the country's demographic development. The total birth rate among rural population fell from 12.7\% in 1990 to $10.3 \%$ in 2006 (table 2).

\begin{tabular}{|c|c|c|c|c|c|c|}
\hline Years & $\begin{array}{c}\text { Birth rate, } \\
\% o\end{array}$ & $\begin{array}{c}\text { Death rate, } \\
\% \circ\end{array}$ & $\begin{array}{c}\text { Natural } \\
\text { increase } \\
\text { rate, } \%\end{array}$ & $\begin{array}{c}\text { Infant } \\
\text { mortality } \\
\text { rate, } \% \text { o }\end{array}$ & $\begin{array}{c}\text { Marriage } \\
\text { rate per } \\
1,000 \text { of } \\
\text { population }\end{array}$ & $\begin{array}{c}\text { Divorce rate } \\
\text { per } 1,000 \text { of } \\
\text { population }\end{array}$ \\
\hline 1990 & 12.7 & 16.1 & -3.4 & 11.9 & 7.9 & 1.6 \\
\hline 1991 & 12.6 & 17.2 & -4.6 & 13.0 & 8.4 & 1.7 \\
\hline 1992 & 12.5 & 17.6 & -5.1 & 12.4 & 6.8 & 1.8 \\
\hline 1993 & 12.0 & 18.5 & -6.5 & 13.0 & 7.4 & 1.9 \\
\hline 1994 & 11.6 & 18.8 & -7.2 & 13.2 & 7.1 & 1.8 \\
\hline 1995 & 11.1 & 19.1 & -8.0 & 13.5 & 7.4 & 1.9 \\
\hline 1996 & 10.7 & 19.2 & -8.5 & 12.4 & 5.6 & 1.8 \\
\hline 1997 & 10.2 & 18.9 & -8.7 & 11.7 & 6.2 & 1.9 \\
\hline 1998 & 9.9 & 18.1 & -8.2 & 10.6 & 5.6 & 1.9 \\
\hline 1999 & 9.3 & 18.5 & -9.2 & 10.6 & 6.2 & 1.9 \\
\hline 2000 & 9.2 & 18.8 & $\begin{array}{l}-9.6 \\
\end{array}$ & 9.9 & 5.0 & 2.2 \\
\hline 2001 & 8.7 & 18.6 & -9.9 & 9.4 & 5.4 & 2.1 \\
\hline 2002 & 9.0 & 19.1 & -10.1 & 8.7 & 5.4 & 2.4 \\
\hline 2003 & 9.1 & 19.6 & -10.5 & 8.1 & 6.0 & 2.5 \\
\hline 2004 & 9.3 & 19.6 & -10.3 & 8.6 & 4.5 & 2.5 \\
\hline 2005 & 9.4 & 20.5 & -11.1 & 9.6 & 5.2 & 2.7 \\
\hline 2006 & 10.3 & 19.8 & -9.5 & 9.4 & 5.6 & 2.7 \\
\hline
\end{tabular}

Tab 2. Dynamics of selected indicators of demographic situation in rural population in Ukraine in 1990-2006

Source: materials of State Statistics Committee of Ukraine.

Today it is the lowest within the whole of Ukraine's post-war history. It is connected with a number of different factors such as drastic worsening of rural population's living standards, high divorce rate, bad health state of women of reproductive age, psychosocial tension, increase in the secondary infertility rate as a result of abortions and others. The Kyiv Institute of Sociology (Žylka 2005) estimates that per 1,000 women of reproductive age as many as 68 suffer from infertility, which causes losses in the birth rate reaching $10 \%$ in total. It seems that socio-economic transformations increase profound destructive changes in Ukraine's demographic situation. This results from the creation of a new system of values and imitation of European family models, also in rural areas. 
The aforementioned Kyiv Institute of Sociology found that the desired number of children in Ukraine is currently 1.9 in cities and 2.0 in the country. However, this family model has been realized by only $68 \%$ of the interviewed women, mainly due to low income and bad living conditions (table 3).

\begin{tabular}{|l|r|}
\hline Reasons & Share of respondents, \% \\
\hline Lack of money & 22 \\
\hline Bad living conditions & 22 \\
\hline Living for self-satisfaction & 20 \\
\hline Lack of state policy In terms of family support & 14 \\
\hline Political and economic destabilization within & 10 \\
\hline Large expenditure connected with childbirth & 10 \\
\hline Lack of necessary pregnancy care & 8 \\
\hline Reluctance of one of the spouses to have a child & 6 \\
\hline Rother reasons & 5 \\
\hline
\end{tabular}

Tab 3. Reasons for the delay in having a child in Ukraine, 2003*

* respondent could choose one or more answers.

Source: Moloda sim'ja v Ukrajini...2003.

In 2006 the total fertility rate of rural women was 1.530 and the average age of a woman at childbirth - 24.8. It is quite a young age in comparison to other European countries, eg. Germany (29) or Denmark (30), however, it has a rising tendency. Socio-economic transformations deepened the process of the transformation of a traditional rural family from $2+3$ model into 2+2 one. They also caused the growth in the number of single-parent families, especially single mothers bringing up children, extramarital births (from $12.4 \%$ of all the births in 1989 to $21.9 \%$ in 2006). What seems a particularly complex problem in rural areas is the population's disproportion by gender: in 2006 there were 114 women per 100 men. However, as to the reproductive age, the tendency is reversed. There are 95 women per 100 men, which is mainly a result of the outflow of rural women. The disproportion of the rural population by gender is one of the factors influencing the decline in the marriage rate and growth in the divorce rate. While in 1980 every seventh rural family broke up, in 2006 - it concerned every second one. The age structure of women having their first child changed significantly (fig. 2). Currently one can observe a high share of teenage mothers (under 20 years of age) reaching $19 \%$.

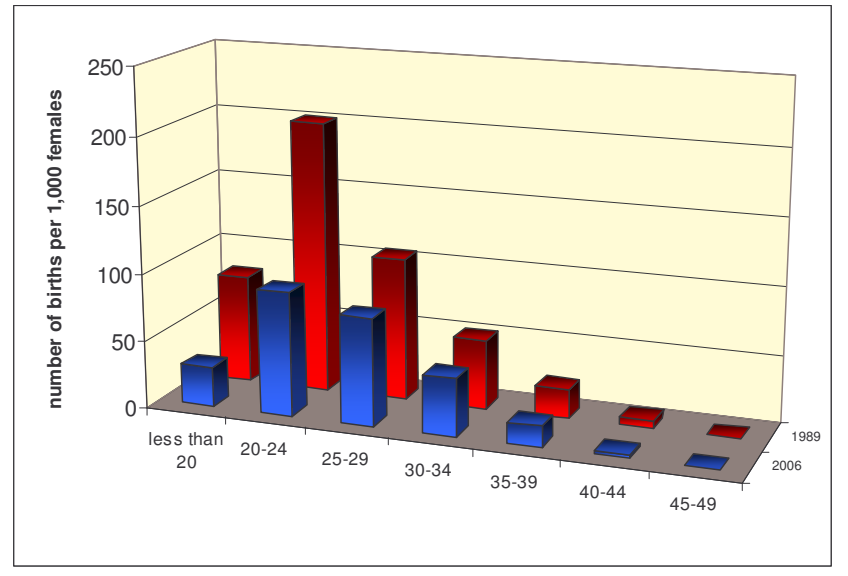

Fig 2. Birth dynamics by age for rural women of reproductive age in 1989-2006

Source: own elaboration based on: Naselennja Ukrajiny ... 1994, Naselennja Ukrajiny 2007.

Legal abortions in state health centres has remained a complex problem for a long time. Their number was the largest in 1990. Later it started to drop quite markedly (table 4). 


\begin{tabular}{|c|c|c|c|c|c|c|c|}
\hline Specification & 1985 & 1990 & 1995 & 2000 & 2002 & 2004 & 2006 \\
\hline Abortions, in thousands & 1,179 & 1,019 & 740 & 434 & 346 & 289 & 230 \\
\hline per 1000 women aged $15-49$ & 88.6 & 82.6 & 58.2 & 34.1 & 27.6 & 23.2 & 18.7 \\
\hline $\begin{array}{l}\text { per } 100 \text { childbirths (including } \\
\text { dead births) }\end{array}$ & 154.0 & 155.0 & 150.0 & 113.0 & 89.0 & 68.0 & 51.0 \\
\hline
\end{tabular}

Tab 4. Dynamics of abortions in Ukraine in 1985-2006

Source: own elaboration based on: Statystyčni ščoričnyky Ukrajiny for different years.

While in 1996 the main reason for decline in the childbirth rate was the decrease in the number of rural women resulting from their outflow from rural areas, beginning from 1997 the main cause of it was the disturbance of the reproductive function among women of reproductive age.

In Ukraine there are three zones of different total fertility rates among women: the first one - of the lowest indices - is situated in the east in a highly industrialized and ecologically degraded part of the country. Another one is located in the southern and central part of the country offering slightly better conditions. The third one is situated in the west, and it has the highest total fertility rate (fig. 3).

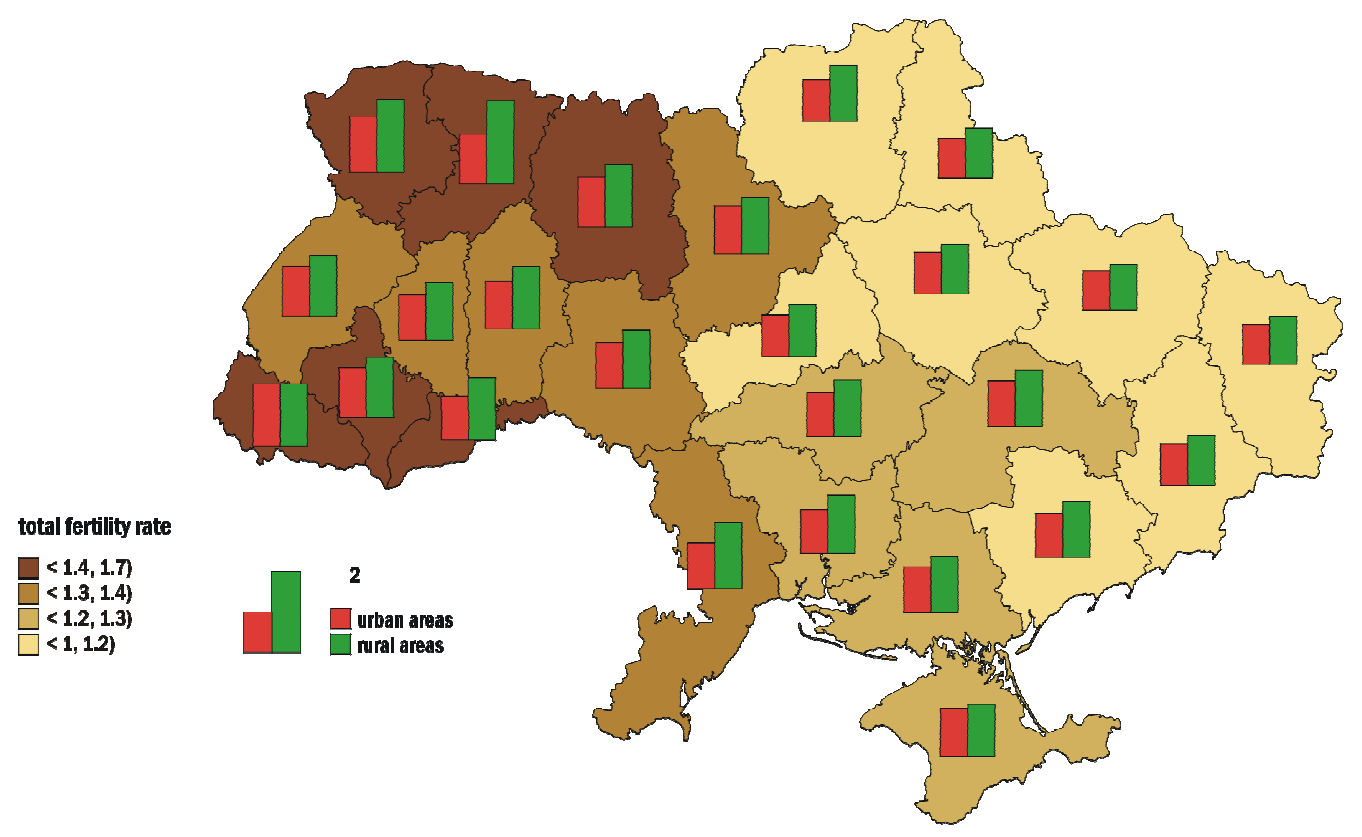

Fig 3. Total fertility rate of women in Ukraine according to the place of residence in 2006

Source: own elaboration based on: Naselennja Ukrajiny...2007.

\subsection{Mortality rate of rural population}

In the conditions of systematic decline in the birth rate, there can be observed constant increase in the number of deaths and a decline in the life expectancy of rural population. The mortality rate of rural population in 2006 was $19.8 \%$ and was twice as high as in 1970. In the research period the highest mortality rate was recorded in 1996 - i.e. during the period of the most profound economic crisis in Ukraine - as well as in 2003-2006. In the spatial aspect, the highest mortality was typical for the central part of the country. The worst situation was observed in Chernihiv province, where the mortality rate among rural population was $30.3 \%$ in 2006 , i.e. four times as high as the birth rate (a region which was the most seriously affected by the Chernobyl disaster). The analysis of the mortality rate dynamics by age found that it grew constantly among people of productive age (table 5). 


\begin{tabular}{|c|c|c|c|c|c|c|c|c|}
\hline \multirow{3}{*}{$\begin{array}{l}\text { Age, } \\
\text { years }\end{array}$} & \multicolumn{4}{|c|}{ Urban population } & \multicolumn{4}{|c|}{ Rural population } \\
\hline & \multicolumn{2}{|c|}{1989} & \multicolumn{2}{|c|}{2006} & \multicolumn{2}{|c|}{1989} & \multicolumn{2}{|c|}{2006} \\
\hline & $M$ & $F$ & $M$ & $F$ & $M$ & $F$ & $M$ & $F$ \\
\hline total & 15,19 & 15,21 & 20,81 & 18,73 & 10,29 & 9,56 & 16,63 & 12,93 \\
\hline $0-4$ & 4,13 & 3,08 & 2,74 & 2,25 & 3,56 & 2,53 & 2,43 & 1,71 \\
\hline $5-9$ & 0,73 & 0,44 & 0,45 & 0,31 & 0,56 & 0,32 & 0,39 & 0,23 \\
\hline $10-14$ & 0,61 & 0,32 & 0,44 & 0,26 & 0,45 & 0,29 & 0,34 & 0,21 \\
\hline $15-19$ & 1,55 & 0,81 & 1,38 & 0,58 & 1,09 & 0,45 & 0,92 & 0,4 \\
\hline $20-24$ & 3,14 & 0,79 & 3,1 & 0,79 & 1,84 & 0,54 & 1,86 & 0,59 \\
\hline $25-29$ & 3,39 & 0,82 & 4,39 & 1,17 & 2,42 & 0,59 & 3,72 & 1,2 \\
\hline $30-34$ & 4,18 & 1,17 & 6,28 & 1,64 & 2,94 & 0,87 & 5,83 & 1,89 \\
\hline $35-39$ & 5,62 & 1,66 & 8,27 & 2,3 & 3,88 & 1,29 & 7,76 & 0,26 \\
\hline $40-44$ & 7,47 & 2,46 & 11,72 & 3,23 & 5,36 & 1,97 & 11,05 & 3,16 \\
\hline $45-49$ & 11,55 & 3,81 & 16,69 & 4,62 & 9,23 & 3,31 & 14,68 & 4,33 \\
\hline $50-54$ & 15,04 & 5,39 & 23,56 & 7,42 & 12,88 & 5,07 & 20,15 & 6,15 \\
\hline $55-59$ & 20,07 & 7,7 & 30,73 & 11,64 & 19,92 & 8,31 & 26,75 & 9,38 \\
\hline $60-64$ & 28,86 & 11,43 & 43,13 & 16,11 & 29,3 & 13,23 & 37,51 & 14,12 \\
\hline $65-69$ & 40,47 & 18,86 & 55,81 & 23,7 & 42,37 & 21,88 & 50,22 & 22,26 \\
\hline 70 and older & 101,25 & 74,69 & 105,01 & 81,34 & 98,71 & 76,87 & 99,7 & 79,07 \\
\hline
\end{tabular}

Tab 5. Dynamics of mortality rate by age groups in Ukraine per 1,000 inhabitants in 1989-2006

$M$ - male; F- female.

Source: own calculation based on: Naselennja Ukrajiny... 1994; Naselennja Ukrajiny...2007.

In 1990-2006 the mortality rate among men of productive age increased more than twice and was 1.5 as high as the women's mortality rate in respective age groups. The fact that the death rate among men outnumbers that of women is connected with their more risky behaviour and health hazard conditions they usually work in. The suicide death rate is growing rapidly among rural men under 50. For men under 24, the death rate in rural areas is higher than the respective rate among urban population. They die mainly due to traumas, food poisoning, murders, suicide and accidents as a consequence of poor availability of medical aid as far as distance and finances are concerned. The average life expectancy of rural population is slightly and systematically decreasing. While in 1992-1993 it was 73.4 years of age among women and 62.3 among men, in 2003-2004 it was respectively 73.8 and 61.8 (Naselennja 2007). The lowest average life span was recorded in 1996. High disproportions of average life span by gender are connected with the overmortality of men mainly of productive age caused by blood circulatory diseases, cancer and a high rate of accidents, murders and suicide. There is still a high death rate caused by AIDS, tuberculosis (respective death rate index caused by this disease is 26 times as high as in the countries of the "old" European Union). As for the death rate caused by tuberculosis, the poorest regions of the country - rural areas of the western part of Ukraine, except for Lviv and Transcarpathian provinces, are the most seriously affected. Worryingly, during the last 5 years the morbidity rate of the active form of tuberculosis among rural population has grown up to almost $40 \%$. The average age of deaths resulting from blood circulation diseases tends to decrease both among rural and urban population

Nowadays the level of mortality rate is mainly influenced by blood circulation diseases and cancer, which in the case of Ukraine are responsible for $72 \%$ of deaths. In turn, the incidence of these diseases is directly affected by the state of natural environment, the population's living conditions and style of life as well as health culture. The percentage of blood circulation diseases in 1990-2006 grew by as much as 36\%, and it mainly concerned men rather than women (table 6). 


\begin{tabular}{|c|c|c|c|c|}
\hline \multirow[t]{2}{*}{ Specification } & \multicolumn{2}{|c|}{$\begin{array}{c}\text { Urban } \\
\text { population }\end{array}$} & \multicolumn{2}{|c|}{$\begin{array}{c}\text { Rural } \\
\text { population }\end{array}$} \\
\hline & 1989 & 2006 & 1989 & 2006 \\
\hline All causes & 981.6 & 1,451 & 1,523 & 1,980 \\
\hline Some infectious and parasite diseases & 10.4 & 37.6 & 14.2 & 29.0 \\
\hline Cancer & 190.5 & 197.2 & 200.8 & 184.5 \\
\hline $\begin{array}{l}\text { Blood and hematopoetic organs diseases and some diseases involving auto immunological } \\
\text { mechanisms }\end{array}$ & 0.9 & 0.7 & 1.0 & 0.8 \\
\hline Endocrinous secretion, nutrition and metabolism disorders & 6.6 & 7.1 & 6.2 & 6.3 \\
\hline Nervous system diseases & 6.7 & 13.5 & 9.3 & 14.9 \\
\hline Circulatory system diseases & 551.1 & 893.8 & 909.3 & 1312 \\
\hline Respiratory system diseases & 44.5 & 38.5 & 135.7 & 83.4 \\
\hline Digestive system diseases & 29.5 & 67.7 & 31.5 & 58.2 \\
\hline Bone and joint diseases and connective tissue diseases & 1.4 & 1.5 & 1.8 & 1.9 \\
\hline Urogenital diseases & 11.6 & 7.4 & 10.5 & 6.7 \\
\hline Some conditions beginning during perinatal period & 7.3 & 4.1 & 3.9 & 4.0 \\
\hline Inborn defects, deformities and chromosome abberrations & 7.2 & 4.3 & 7.4 & 5.4 \\
\hline External causes of diseases or deaths & 92.8 & 127.7 & 119.2 & 159.9 \\
\hline
\end{tabular}

Tab 6. Dynamics of mortality rate by main causes per 100, 000 inhabitants in Ukraine in 1989-2006

Source: own elaboration based on: Naselennja Ukrajiny...1994, Naselennja Ukrajiny...2007.

It is connected with men's alcohol abuse, smoking habits and unhygienic style of life. In Ukraine the areas most threatened by blood circulatory diseases are those which were the most seriously affected by the Chernobyl catastrophe (Chernihiv, Zhytomyr and Kyiv provinces) (fig. 4).

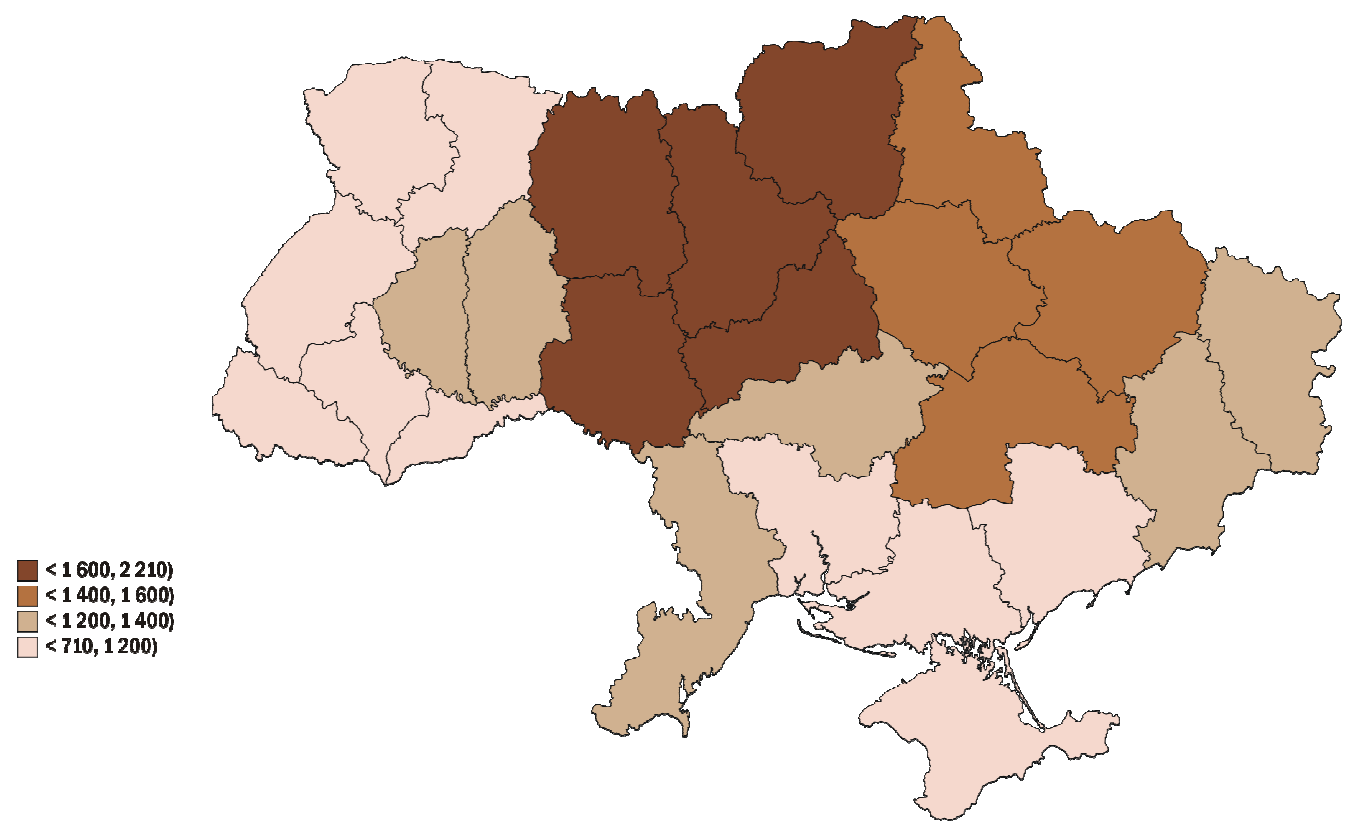

Fig 4. Death rate caused by blood circulatory diseases among rural population in Ukraine per 100,000 inhabitants in 2006

Source: own elaboration based on: Naselennja Ukrajiny...2007.

Comparing the level of mortality rate caused by the above mentioned reason in the time-spatial aspect, it can be concluded that in 2006 in relation to 1990, the situation in terms of the death rate caused by circulatory system diseases worsened significantly (Pantyley 2008).

Another, second death cause among both rural and urban population is cancer, whose share in the total number of deaths is c. $15 \%$. Malignant tumour mortality rate is higher among men. They mainly suffer from the malignant tumour of trachea, bronchi and lungs, followed by those of stomach and colon. Women are affected by mammary cancer, malignant tumours of cervix, colon, trachea, bronchi and lungs. The increasing level of malignant tumour death rate can be mainly connected with the increased exposition to carcinogenic factors and the style of life which is conducive to the development of cancer (smoking, alcohol and drug abuse) and to the 
general deterioration of the population's living conditions, bad ecological situation, low effectiveness of early cancer diagnosis and treatment (Atlas of cancer mortality in Central Europe...1996). Undoubtedly, in Ukraine a very important factor that increases malignant tumour incidence is the unfavourable ecological situation worsened by the Chernobyl disaster. In spatial depiction, the worst situation can be observed in the provinces of: Donetsk, Kyiv, Kchmelnytskyy, Chernihiv.

The third most significant reason for the death rate of Ukraine's rural population is transport accidents, followed by drowning, food poisoning, suicide and murder, all of them regarding as external causes. Their share in the total death number is over $10 \%$. In relation to 1989, in 2006 the death rate caused by external reasons was 1.4 times higher. One of the reasons for such a ituation in Ukraine is the high mortality rate caused by alcohol abuse. According to WHO data, at the beginning of the period of intensive socio-economic transformations annual alcohol consumption in pure spirit in Ukraine could be estimated at even 20 I per person (Zatoński 2001). Also according to the data of the Ukrainian Information Centre, over the last 10 years alcoholic beverages consumption in pure spirit has been up to 11-13 I per person (Ochorona zdorov'ja Ukrajiny...2000). In terms of the death rate caused by external reasons, the worst situation in 2006 was in the whole of the southeastern part of Ukraine and Chernihiv, Poltava, Kirovohrad provinces (fig. 5).

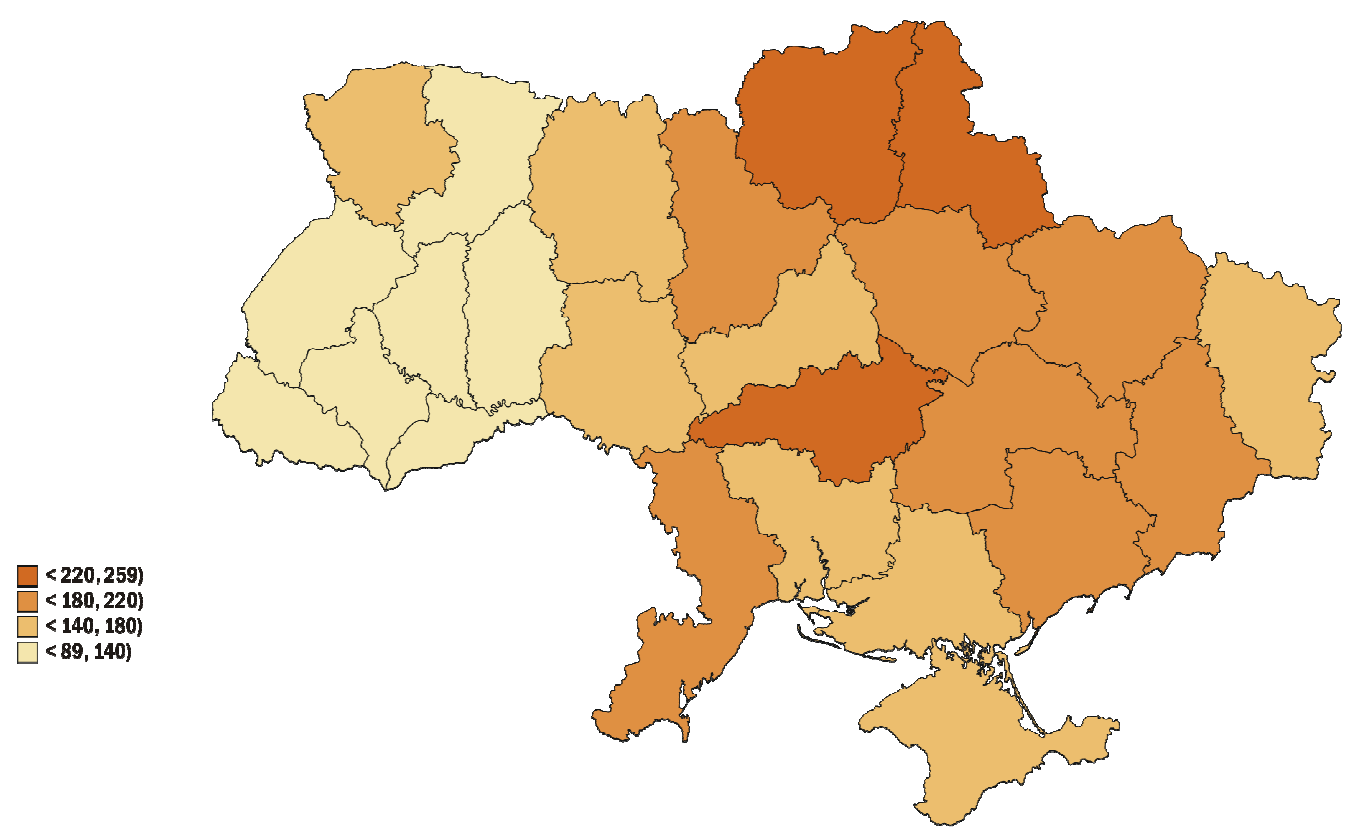

Fig 5. Death rate caused by external reasons among rural population in Ukraine per 100, 000 people in 2006

Source: own elaboration based on: Naselennja Ukrajiny...2007.

\subsection{Infant mortality rate of rural population}

Infant mortality rate has always been regarded as the clearest index of the socio-economic and health situation of countries and regions. It depends on a number of different factors concerning community, medicine, economy and others. These factors have a direct (availability of proper medical care to pregnant women, childbirth and delivery conditions) or indirect influence on the phenomenon of infant mortality rate within a longer period of time (reproductive health of women, style of life, environmental pollution, genetic conditions, general socio-economic situation of countries). During the analysed period the highest infant mortality rate was in 1996, i.e. in the year of the greatest economic breakdown. Later the situation improved significantly. In the initial period of intensive socio-economic changes (1990) the infant mortality rate was clearly higher in the western part of Ukraine (and not in the south like in 2006). The most frequent infant death cause is perinatal diseases, i.e. during pregnancy and the first 6 days of an infant's life. These comprise disorders connected with a shortened pregnancy period and low body weight at childbirth. Others comprise breathing and cardio-vascular disorders, also typical of the 
perinatal period. These two groups cause c. $65 \%$ of infants' deaths. Worryingly enough, within the analysed period the infant mortality rate grew due to external reasons (table 7).

\begin{tabular}{|c|c|c|c|c|}
\hline \multirow[t]{2}{*}{ Specification } & \multicolumn{2}{|c|}{1989} & \multicolumn{2}{|c|}{2006} \\
\hline & Total & $\begin{array}{c}\text { Rural } \\
\text { areas }\end{array}$ & Total & $\begin{array}{c}\text { Rural } \\
\text { areas }\end{array}$ \\
\hline Some infectious and parasite diseases & 0.5 & 0.7 & 1.0 & 1.2 \\
\hline Nervous system diseases & 0.3 & 0.3 & 0.4 & 0.6 \\
\hline Respiratory system diseases & 0.4 & 0.6 & 1.6 & 2.4 \\
\hline Some conditions beginning during perinatal period & 4.2 & 3.9 & 4.6 & 2.9 \\
\hline External causes & 0.8 & 1.1 & 0.7 & 1.0 \\
\hline
\end{tabular}

Tab 7. Dynamics of infant mortality rate by reasons in Ukraine in 1989-2006 per 1000 live births

Source: own elaboration based on: Naselennja Ukrajiny...1994, Naselennja Ukrajiny...2007.

The high maternal mortality rate connected with infants' deaths is an important problem. In 2004 it was almost 5 times as high as in Poland and other EU countries but lower than in CIS (1.5 times) (WHO/Europe...2007). Among the reasons for mothers' deaths there are mainly pregnancy and labour complications, outside the hospital abortion and pregnancy toxicosis (table 8).

\begin{tabular}{|c|c|c|c|c|c|c|c|c|c|}
\hline \multirow[b]{2}{*}{ Causes } & \multicolumn{3}{|c|}{1996} & \multicolumn{3}{|c|}{2000} & \multicolumn{3}{|c|}{2004} \\
\hline & Total & $\begin{array}{l}\text { Urban } \\
\text { areas }\end{array}$ & $\begin{array}{l}\text { Rural } \\
\text { areas }\end{array}$ & Total & $\begin{array}{l}\text { Urban } \\
\text { areas }\end{array}$ & $\begin{array}{l}\text { Rural } \\
\text { areas }\end{array}$ & Total & $\begin{array}{l}\text { Urban } \\
\text { areas }\end{array}$ & $\begin{array}{l}\text { Rural } \\
\text { areas }\end{array}$ \\
\hline All causes & 30.4 & 31.3 & 29.0 & 24.7 & 21.4 & 29.9 & 13.1 & 12.7 & 14.0 \\
\hline Resulting from hospital abortion & 0.6 & 0.3 & 1.1 & 0.3 & 0.4 & $\ldots$ & 0.7 & 0.4 & 1.4 \\
\hline $\begin{array}{l}\text { Resulting from out-of-hospital } \\
\text { abortion }\end{array}$ & 5.4 & 5.2 & 5.7 & 4.2 & 4.2 & 4.1 & 1.2 & 1.1 & 1.4 \\
\hline Pregnancy and labour bleeding & 3.6 & 3.8 & 3.4 & 2.1 & 2.1 & 2.0 & 1.2 & 1.1 & 1.4 \\
\hline Pregnancy toxicosis & 3.0 & 3.8 & 1.7 & 2.1 & 0.8 & 4.1 & 1.6 & 1.4 & 2.1 \\
\hline Blood infection during pregnancy & 1.5 & 1.7 & 1.1 & 1.8 & 1.7 & 2.0 & 0.9 & 1.1 & 0.7 \\
\hline $\begin{array}{l}\text { Other pregnancy and labour } \\
\text { complications }\end{array}$ & 15.2 & 15.1 & 15.3 & 13.8 & 11.8 & 17.0 & 7.5 & 7.7 & 7.0 \\
\hline
\end{tabular}

Tab 8. Dynamics of maternal death rate in Ukraine per 100, 000 live births according to the place of residence in 1996-2006

... absent data.

Source: own elaboration based on: Social'ni indykatory rivnja žyttja...2005.

\subsection{Ageing of rural population}

The basic measure of demographic old age used in demographics is the share of the population at the age of 60 (or 65) and over 60 in its total number. Countries commonly considered as old are those with the share of people aged 65 and more exceeding $7 \%$ (Narodonasielienije... 1994). According to 2006 data, in Ukraine's rural areas the percentage of such people was c. $20.0 \%$ while in urban areas it reached the value of $14.6 \%$. Provinces which have the highest old age rates are concentrated in the central part of Ukraine.

It must be noted that the spatial distribution of demographic old age is quite constant and since 1990 it has not changed considerably. It means that in the "old" regions the share of people of post-productive age is still growing, as compared to the areas which are demographically "younger". As a result of the above analysed tendencies, the population age pyramid in Ukraine has undergone considerable changes. It transformed from stagnation to a clearly regressive type. According to Ukrainian age pyramid of 2001, older age groups are dominated by women, and younger ones by men. In comparison to 1959 there can be observed narrowings in some age groups. They are the effects of population decline as a result of wars, famine or political repressions. The narrowing of the pyramid at its central part (age group 56-59) was caused by birth decrease of births during and after World War II. Another narrowing (age group of 67-68) reflects famine in Ukraine in 1933-1934. A characteristic feature of the pyramid is a large disproportion of gender, especially noticeable in the range above 35 years of age (fig. 6). The 
migratory outflow of rural women of reproductive age (aged 20-29) induces their low share in rural areas (barely $48 \%$ of the total population of the same age).

The most obvious effect of population's ageing in Ukraine is the growth in the demographic burden of the population. The largest number of the population of post-productive age per 1,000 productive age people is typical of all the northern and central part of Ukraine, except for Kyiv province. Worryingly, the problem of increased demographic burden largely affects urban population, which can be clearly observed in Ukrainian central regions (fig. 7).

According to demographic forecasts, the problem of old age in Ukraine will become more serious and vivid after 2010, when the generation of the post-war demographic boom starts to enter its post-productive age. It will give rise to huge economic problems and deepen those concerning medical care (Gnybidenko at al. 2003). The rural population decline usually takes place as a result of the pre-productive age population decrease and simultaneous growth in pensioners' number, both in relative and absolute numbers. The consequence of that is the progressive population ageing in rural and urban areas in Ukraine. According to the data of the Ministry of Labour and Social Policy in 2005 there were registered c. $13 \mathrm{mln}$ pensioners, among whom c. $3 \mathrm{mln}$ were the disabled, $5 \mathrm{mln}$ veterans of war and labour.

The problem of demographic old age is strictly connected with its typical ailments (brain vessel diseases, hypertension, myocardial ischaemia, malignant tumours) including chronic diseases and generally poor fitness. Selective tests run by the Ukrainian Institute of Public Health (Kyiv) proved that $90-95 \%$ of the population aged $60-64$ and only $25 \%$ aged 80 or above remain physically active.

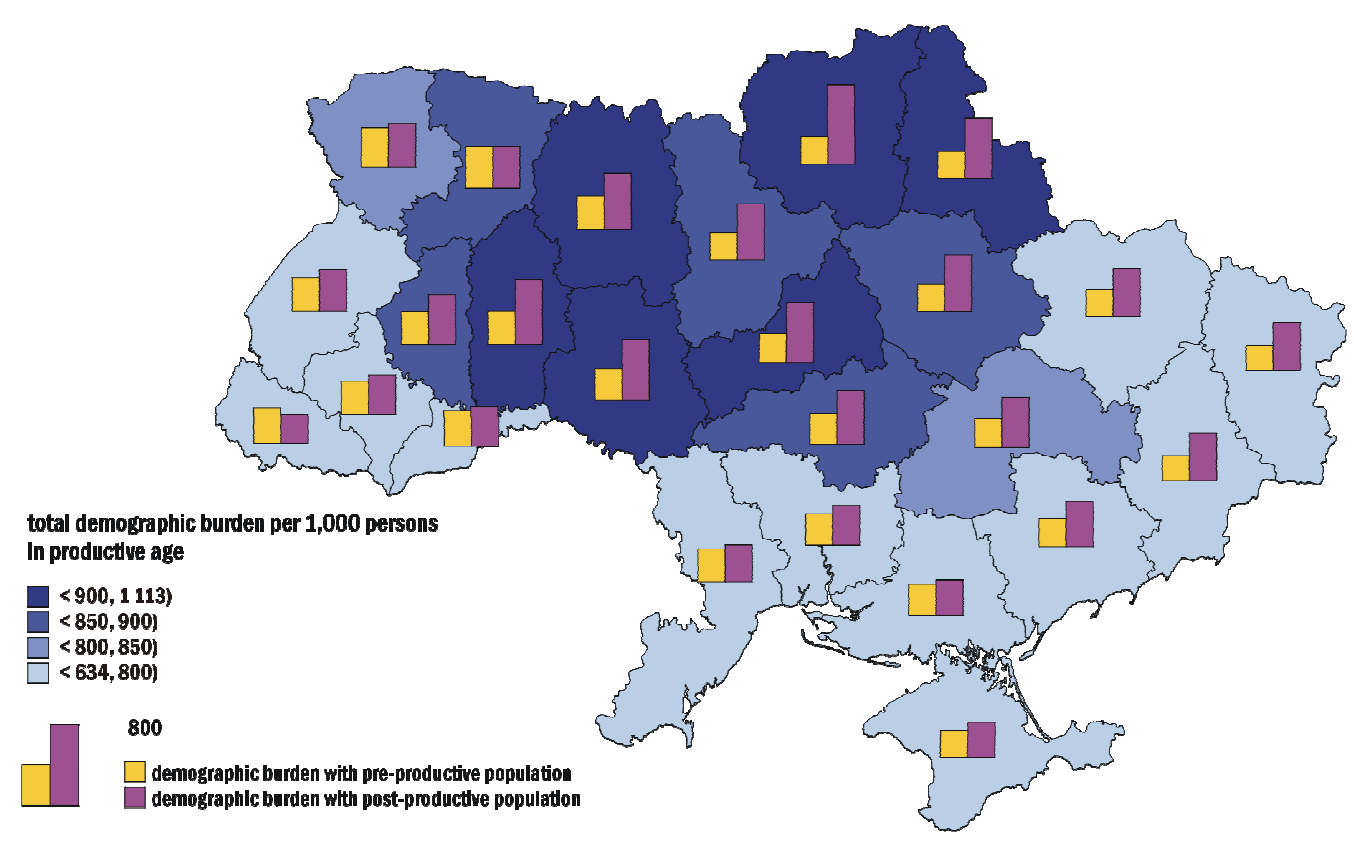

Fig 7. Demographic burden of rural population per 1,000 people of productive age in Ukraine in 2006

Source: own elaboration based on Naselennia Ukrajiny...2007.

\subsection{Natural increase and migration rates}

The result of the unfavourable changes of the above analysed elements of the demographic situation is the negative natural increase of the population. While in 1980 the respective rate for rural areas was $-0.7 \%$, in 2005 it reached the value of $-11.1 \%$. Such a dramatic situation concerning the natural increase rate is a consequence of cumulated effects of low birth rate and high death rate. Among the rural areas in Ukraine the most dramatic situation concerns the districts situated in the north and east of the country, particularly Chernihiv, Sumy and Poltava provinces. Their condition results mainly from the deformation of the gender and age structure, from men's overmortality and the effects of the Chernobyl disaster. 
As results from the comparison of the changes within natural increase rates observed in recent years, the rates underwent quite a smooth regression within particular units. Therefore, the general image of natural increase rate spatial distribution remained practically unchanged (fig. 8, 9).
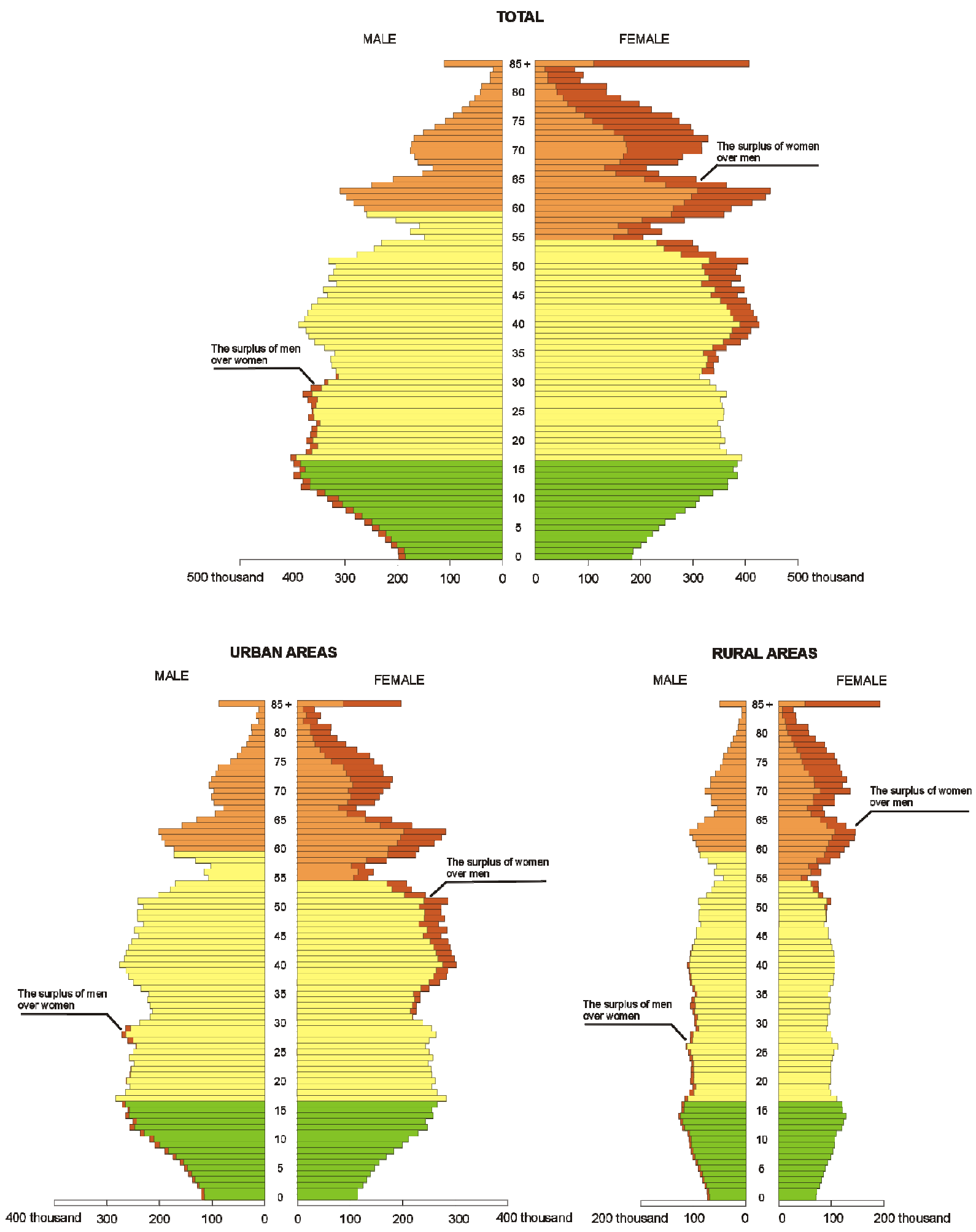

Fig 6. Ukraine's population by age and gender, 2001

Source: own elaboration based on the data of Ukraine's State Statistics Committee. 


\subsection{Natural increase and migration rates}

The result of the unfavourable changes of the above analysed elements of the demographic situation is the negative natural increase of the population. While in 1980 the respective rate for rural areas was $-0.7 \%$, in 2005 it reached the value of $-11.1 \%$. Such a dramatic situation concerning the natural increase rate is a consequence of cumulated effects of low birth rate and high death rate. Among the rural areas in Ukraine the most dramatic situation concerns the districts situated in the north and east of the country, particularly Chernihiv, Sumy and Poltava provinces. Their condition results mainly from the deformation of the gender and age structure, from men's overmortality and the effects of the Chernobyl disaster.

As results from the comparison of the changes within natural increase rates observed in recent years, the rates underwent quite a smooth regression within particular units. Therefore, the general image of natural increase rate spatial distribution remained practically unchanged (fig. 8, 9).

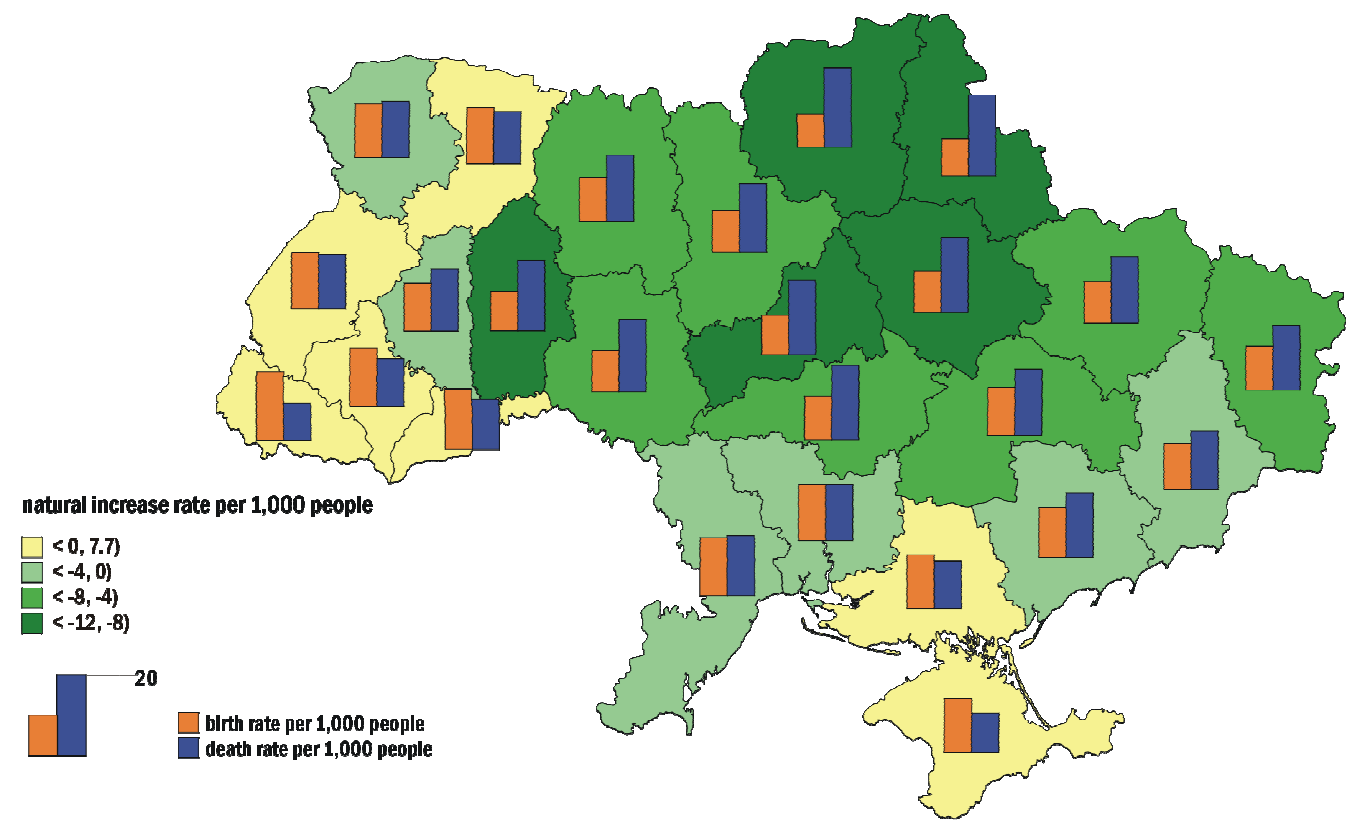

Fig 8. Natural increase rate of rural population per 1,000 inhabitants in Ukraine in 1990

Source: own elaboration based on: Naselennja Ukrajiny... 1993.

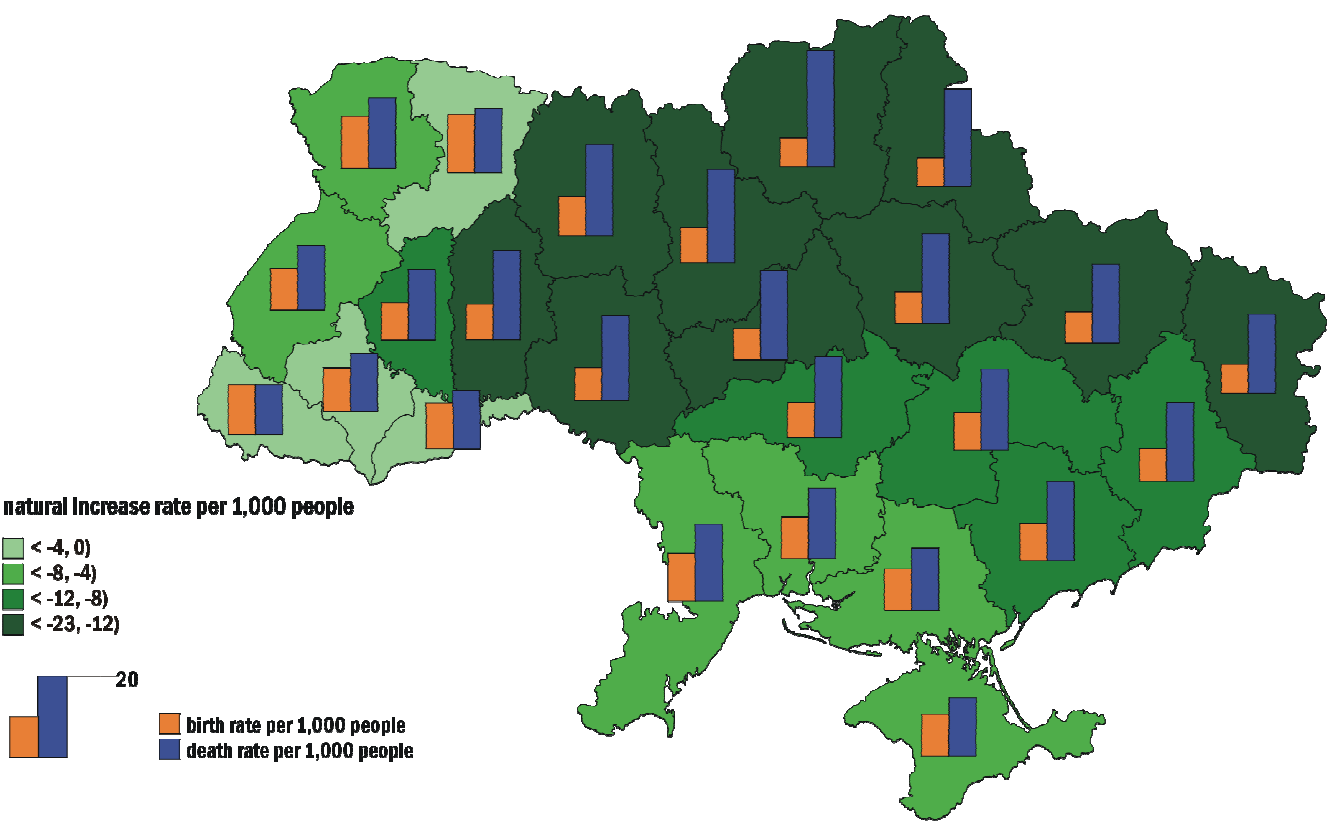

Fig 9. Natural increase rate of rural population per 1,000 inhabitants in Ukraine in 2006

Source: own elaboration based on: Statystyčnyj ščoričnyk Ukrajiny...2007. 
The constant migratory movement influences the quantity and quality of Ukrainian population's composition. In 1960-1975 it was responsible for the decline in the rural population number by 80\% (Rogožyn 2004). In 1976-2006 the role of the natural movement factor was, however, higher than that of migratory movement. The migration scale was then very equivocal. A drastic decrease in living standards, especially in the initially difficult transformation period, the inability to obtain a free dwelling in the city forced almost 500,000 urban population to migrate towards the village in 1991-1993. However, as early as in 1993-1996, the absolute migration value decreased 10 times shifting the movement vector from the village to the city. As a consequence, Ukrainian villages are dying out (table 9). A negative effect of migratory processes is that these are mainly elderly people who arrive in Ukraine whereas well-educated and healthy young people $(80 \%$ - people under 30$)$ leave their country.

It is typical of Ukraine that its rural population emigrates mainly abroad in order to obtain income, usually illegally. It is estimated that currently from $5 \mathrm{mln}$ to $7 \mathrm{mln}$ Ukrainian people are staying abroad for money earning reasons (Ševčuk 2003). External money-earning migration is directed towards European countries. However, the eastbound EU enlargement and the visa regime introduction complicated the population's migration in this direction. Russia, in turn, is becoming another migratory destination of labour force. According to unofficial data, moneyearning emigration to Russia is c. 3.5-5.5 mln people. According to official data it is only 320340 people (Ekonomika Ukrajiny...2003).

While in 1960-1995 the rural population number was mainly influenced by the migratory outflow, which at $30-60 \%$ was compensated by the population growth, in 1996-2006 the most important factor conditioning the population decline was the population loss rate. Currently it is responsible for the depopulation of rural areas at 85-95\% (Rogožyn 2004).

\begin{tabular}{|c|c|c|c|}
\hline Territorial units & 1990 & 1996 & 2001 \\
\hline Ukraine & 8.9 & 9.1 & 10.1 \\
\hline AR Crimea & 2.7 & 2.4 & 4.6 \\
\hline Vinnytsia & 5.3 & 6.1 & 7.4 \\
\hline Volyn & 2.8 & 2.2 & 2.8 \\
\hline Dnipropetrovsk & 11.2 & 10.2 & 12.6 \\
\hline Donetsk & 8.3 & 10.7 & 12.5 \\
\hline Zhytomyr & 6.5 & 7.3 & 9.4 \\
\hline Transcarpathian & 0.2 & 0.3 & 0.2 \\
\hline Zaporizhia & 8.4 & 7.4 & 9.3 \\
\hline Ivano-Frankivsk & 0.8 & 1.7 & 1.4 \\
\hline Kyiv & 6.9 & 9.5 & 10.2 \\
\hline Kirovohrad & 12.7 & 12.3 & 14.9 \\
\hline Luhansk & 12.7 & 12.8 & 17.2 \\
\hline Lviv & 2.2 & 2.5 & 3.9 \\
\hline Mykolajiv & 8.3 & 6.7 & 9.9 \\
\hline Odessa & 6.7 & 6.5 & 8.5 \\
\hline Poltava & 17.2 & 17.6 & 18.4 \\
\hline Rivne & 2.8 & 2.8 & 2.3 \\
\hline Sumy & 23.5 & 23.3 & 25.1 \\
\hline Ternopil & 1.0 & 1.1 & 1.3 \\
\hline Kharkiv & 19.5 & 19.2 & 17.1 \\
\hline Kherson & 4.6 & 4.1 & 3.9 \\
\hline Kchmelnytskyy & 3.5 & 3.6 & 3.7 \\
\hline Cherkasy & 6.1 & 5.7 & 6.3 \\
\hline Chernivtsi & 0.3 & 0.3 & 0.3 \\
\hline Chernihiv & 19.0 & 20.7 & 21.0 \\
\hline
\end{tabular}

Tab 9. Percentage of rural centers with no children aged 0-5 as to the year beginning

Source: Naselennja i trudovi resursy sela...2002.

\subsection{Selected elements of the level and quality of life among rural population}

For further analysis from among all the elements concerning the level and quality of life there were chosen the following: the employment level and structure, unemployment rate, the level and structure of income and of basic household expenditure, poverty level and the level of satisfaction with one's material situation.

The percentage of the population employed in the primary sector in Ukraine is still very high $25 \%$ of the total employed. In highly developed EU countries it is just a few percent. 
Unfortunately it does not raise the productivity in agriculture, which is now 5-7 times lower than in highly developed countries. In the light of the Ukrainian National Census results in 2001 among rural population $4.4 \mathrm{mln}$ were employed (57\% of the total fit for work). Every fourth of them worked beyond the boundaries of their own village. Every second of them worked in cities and urban-type centres. Around 37,000 of rural population worked beyond their state borders. Their largest percentage was recorded in three western Ukrainian provinces - Chernivtsi (7.3\%), Transcarpathian (5.6\%), Ivano-Frankivsk (2.4\%) provinces. Worryingly, almost $3 \mathrm{mln}$ of rural population, i.e. every third person at the productive age neither studied at any educational level nor worked. Within the structure of the employed population in 2001 c. $55 \%$ worked in agriculture sector, $12 \%$ - in industry and construction, $4.4 \%$ - in transport, and the rest - in the services sector (fig. 10).

Transformation processes brought unemployment which has an absolutely negative influence on the economic situation of the population and triggers many negative phenomena concerning demographic and health spheres. As the latent unemployment scale is large, it is difficult to estimate the factual number of the unemployed among the rural population. Officially, the statistics in this respect are not complete and show lowered indices. In the light of the Ukrainian National Census results in 2001 the number of the registered unemployed in the village was 466,800 . The number was the largest in three western provinces of Ukraine: Lviv, IvanoFrankivsk and Transcarpathian. The unemployment rate, calculated on the basis of the International Labour Organization was then $7.1 \%$. Another issue concerning unemployment is a large percentage of young people remaining without a job, followed by the long duration of unemployment period. Among rural population in 2001 the unemployment rate was $25.2 \%$ for people aged 15-19 and $11.0 \%$ for people aged 20-29. The causes of unemployment are dominated by redundancy, work place liquidation, voluntary redundancy (it concerned c. $40 \%$ of people aged 30-44 as a consequence of a critically low salary level). In terms of unemployment effects on the demographic and health situation, its duration is a crucial issue. Long out-of-work period is mainly connected with the lack of income, which is the cause of low living standards of the unemployed person and their family. Pathological phenomena (alcoholism, drug abuse) and a considerable suicide rate increase particularly among the unemployed. As results from E. Laiferowa's research (1999), people unemployed for more than 12 months, being off the main stream of social life, create a specific socially isolated culture dependent on welfare institutions. They are not interested in social life but apaethic and deprived of aspirations. The average unemployment duration of the rural population in Ukraine is 23 months; $60 \%$ of the unemployed are people aged 25-39 who are out of work for more than a year.

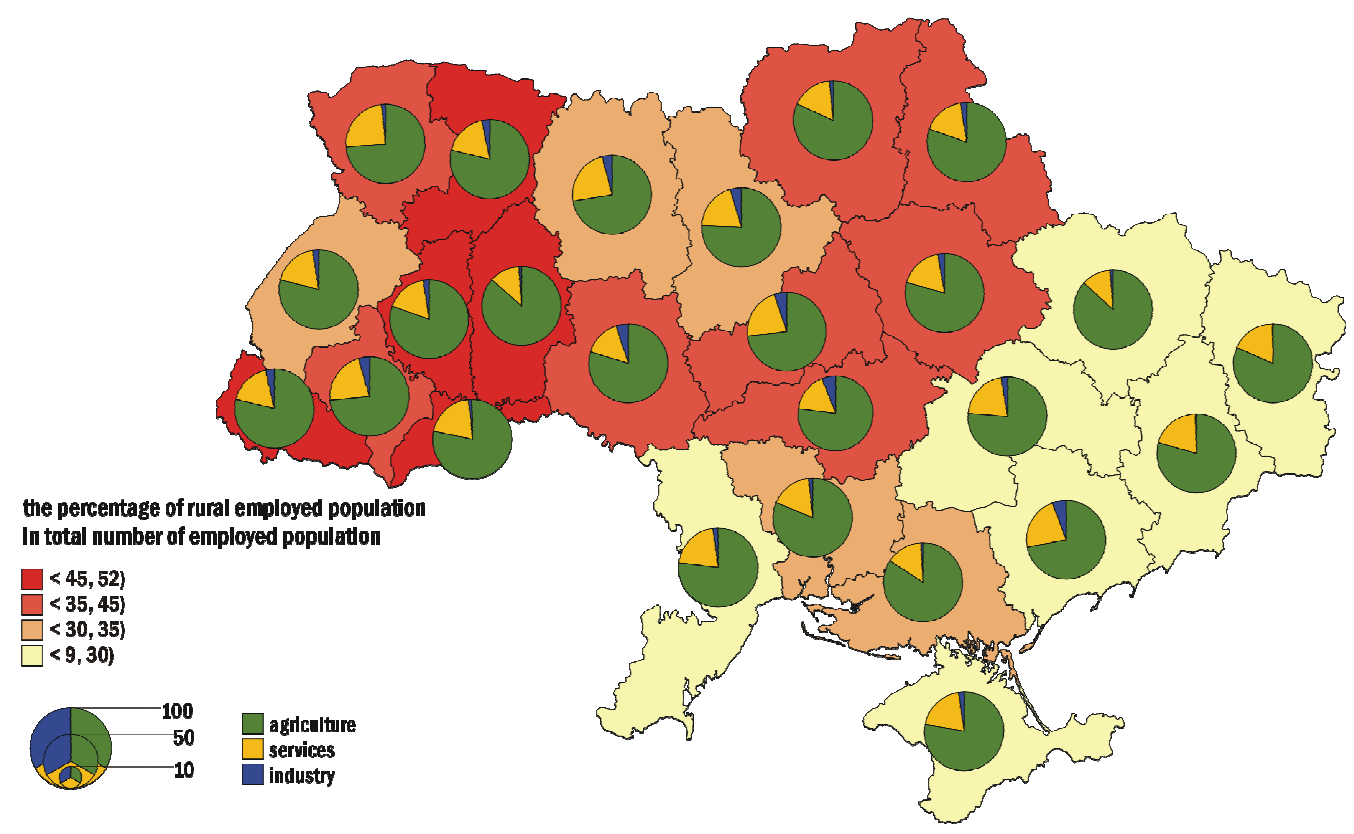

Fig 10. Level and structure of employment of rural population in Ukraine in 2001

Source: own elaboration based on the data of Ukraine's State Statistics Committee. 
Employment in agriculture is connected with high latent unemployment which is estimated at $1.4 \mathrm{mln}$ people (57\% of all the employed in rural areas) (Naselennja and trudovi resursy...2002). The percentage of people working in individual agricultural households is rising especially in AR Crimea, Donetsk, Zaporizhia and Luhansk provinces and in the western part of Ukraine.

The basic source of income in rural and urban households is hired labour, individual agricultural household and retirement pension. In the analysed period the highest income level in an agricultural household was recorded in 1996, when its percentage in the general income structure was $31 \%$. It was a period of the deepest socio-economic crisis and the agricultural income became probably the most important source of income and also the main way for biological survival of the population. Later its percentage started to drop and is currently $5.1 \%$, reaching $14.8 \%$ among rural population (table 10 ).

\begin{tabular}{|l|r|r|r|r|r|r|}
\hline \multicolumn{1}{|c|}{ Income structure } & \multicolumn{2}{|c|}{ By place of residence } & \multicolumn{2}{c|}{ By household type } & $\begin{array}{c}\text { Households } \\
\text { in total }\end{array}$ \\
\cline { 2 - 7 } & City & \multicolumn{1}{c|}{ Town } & Village & $\begin{array}{c}\text { Households } \\
\text { with children }\end{array}$ & $\begin{array}{c}\text { Households } \\
\text { without } \\
\text { children }\end{array}$ & \\
\hline Hired labour & 59.7 & 47.5 & 27.2 & 55.3 & 40.2 & 47.1 \\
\hline $\begin{array}{l}\text { Sale of agricultural household } \\
\text { produce }\end{array}$ & 0.1 & 2.1 & 14.8 & 5.1 & 4.9 & 5.0 \\
\hline $\begin{array}{l}\text { Natural income from } \\
\text { agricultural household }\end{array}$ & 1.3 & 6.5 & 16.9 & 7.7 & 6.9 & 7.2 \\
\hline Social benefits & 23.1 & 27.2 & 26.3 & 13.2 & 34.9 & 25.0 \\
\hline $\begin{array}{l}\text { Other sources including self- } \\
\text { employment }\end{array}$ & 15.8 & 16.7 & 14.8 & 18.7 & 13.1 & \\
\hline
\end{tabular}

Tab 10. Structure of household income in Ukraine according to the place of residence in 2004

Source: own elaboration based on: Liuds'kyj rozvytok...2006.

A large diversification of income along the city-village line is a problematic issue. Urban and agricultural communities were the most seriously affected by the results of economic reforms. The undertaken attempts to de-collectivize agriculture were accompanied by a huge decline in agricultural spending and in animal and plant production. The conducted economic reforms worsened price relations between agricultural and industrial goods. That yet worsened the economic living standards in the village. This is confirmed by statistical data concerning the average monthly salary rate of people employed in agriculture, forestry and fishing industry. In 2006 the average salary rate in the respective categories was only $50-80 \%$ of the total gross monthly salary in the country. In 2006 it was equivalent to 551-851 hryven' per 1 employee, i.e. 109-169 USD. It meant 3.5-5.5 USD daily.

Other criteria concerning the estimation of the rural population's material situation comprise mainly the rate of household expenditure according to households' structure and especially food expenditure. The share of expenses on food is critically high in Ukraine $(64.3 \%$ among all expenses of rural households in 2004). According to the UN the level of critical poverty line is reached when $50 \%$ population's income is spent on food.

Except for the presented above indices characterizing society's affluence level there are many others connected with the possession of durable goods. According to questionnaire research conducted by the State Statistical Committee of Ukraine almost every sixth urban family with many children did not possess a fridge, and every third did not have a washing machine. Today the indices of possessing durable goods can be used to determine the level of poverty according to the property criterion. Having a fridge, a washing machine and a colour TV set is considered an absolute minimum. A household is deemed to be poor if it does not have at least one of the above mentioned goods. In the light of such criteria $45.2 \%$ of rural population is considered to be poor (table 11).

In terms of the average size of a dwelling per person, rural areas are in a more advantageous position ( $25 \mathrm{~m}^{2}$ per person while in urban areas in 2006 a respective index was only $21 \mathrm{~m}^{2}$ ). However, rural dwellings are much more poorly equipped with household appliances. In 2004 only $34 \%$ of rural dwellings had access to gas, $21 \%$ were connected to a water pipeline and $19.5 \%$ to the sewage system. 


\begin{tabular}{|l|r|r|r|}
\hline \multicolumn{1}{|c|}{ Household type } & Ukraine & Urban areas & Rural areas \\
\hline Households with children & 26.0 & 19.5 & 38.0 \\
\hline 1 child & 22.4 & 14.8 & 34.9 \\
\hline 2 children & 26.9 & 20.7 & 34.6 \\
\hline 3 and more children & 48.5 & 34.1 & 58.5 \\
\hline With children under 3 & 27.4 & 19.4 & 40.0 \\
\hline Without children & 35.6 & 27.0 & 34.7 \\
\hline With at least one pensioner & 33.3 & 23.0 & 48.5 \\
\hline Consisting only of pensioner & 66.1 & 54.9 & 84.6 \\
\hline Consisting of two or more pensioners & 38.4 & 26.2 & 60.2 \\
\hline Households in total & 30.4 & 23.1 & 45.2 \\
\hline
\end{tabular}

Tab 11. Poverty level by property criterion in 2004, percentage of households

Source: self-analysis on the basis of the data from the State Statistical Committee of Ukraine.

The level of infrastructure in the Ukrainian village is still critical: c. $82 \%$ of rural areas have no access to a water pipeline, $98 \%$ - to the sewage system, and c. $85 \%$ to a gas pipeline (Rogožyn 2004). According to the data of the Medical Statistics Centre of the Ministry of Health Care around $43 \%(12,000)$ of villages in Ukraine have no medical centres. All the obstetricgynecological centres operating at cooperatives were liquidated. As a result very often rural women deliver their babies at home. This in turn means numerous complications, sometimes even mother's and (or) children's deaths. What makes the situation even worse is the fact that as a rule rural women work excessively for even 11-12 hours a day. This causes their premature ageing and disorder or loss of their reproductive function. In the conditions of increased morbidity and death rate due to circulatory system diseases it is scandalous that the number of cardiologists per person is so dramatically low. At present there is only 1 doctor cardiologist per 30,000 people.

The important moment in the evaluation of living standards and life quality is concerned with a person's satisfaction with the material well-being (table 12). Despite positive tendencies, the percentage of people considering themselves poor or not wealthy people in rural areas is still critically high. In 2006 it exceeded $80 \%$.

\begin{tabular}{|l|r|r|r|r|r|r|}
\hline $\begin{array}{l}\text { According to the standards abiding in your } \\
\text { society, which class do you belong to? }\end{array}$ & \multicolumn{2}{|c|}{ Total } & \multicolumn{2}{c|}{$\begin{array}{c}\text { Urban } \\
\text { population }\end{array}$} & \multicolumn{2}{|c|}{$\begin{array}{c}\text { Village } \\
\text { population }\end{array}$} \\
\cline { 2 - 7 } & $\mathbf{2 0 0 2}$ & $\mathbf{2 0 0 6}$ & $\mathbf{2 0 0 2}$ & $\mathbf{2 0 0 6}$ & $\mathbf{2 0 0 2}$ & $\mathbf{2 0 0 6}$ \\
\hline Poor & 39.6 & 31.2 & 39.8 & 30.7 & 38.8 & 32.5 \\
\hline Not wealthy & 39.3 & 45.6 & 38.4 & 44.9 & 41.4 & 47.7 \\
\hline Middle class & 13.2 & 17.2 & 13.8 & 18.6 & 11.9 & 13.2 \\
\hline Difficult to say & 7.8 & 5.4 & 7.8 & 5.2 & 7.7 & 6.2 \\
\hline Rich & 0.1 & 0.3 & 0.1 & 0.3 & 0.2 & 0.2 \\
\hline Very rich & 0.0 & 0.3 & 0.1 & 0.3 & 0.0 & 0.2 \\
\hline
\end{tabular}

Tab 12. Estimation of one's socio-economic status within society in 2002-2006 [\%]

Source: self-analysis on the basis of Socjalno-ekonomična zachyščenist'...2006

(http://ukrstat.gov.ua/operativ/operativ2006/sz/dop/zahust.htm; 21-05-2008).

\section{Conclusion}

The demographic crisis existing in rural areas of Ukraine since $80 \mathrm{~s}$ is quite special. It is connected with a deep and systematic decline in the birth rate, rapid growth in the death rate in total and because of circulatory system diseases and external causes, which concerns mainly people of productive age. It is also connected with increase in the infants' death rate, drop in the total fertility rate of women and rapidly progressing ageing processes. Except for historical and socio-economic factors, the demographic crisis is largely influenced by successive blocking and falsifying of agricultural reforms. Moreover, reforms are used to the illegal accumulation of initial capital. It is done by former managers of cooperatives and other representatives of political party elites. According to experts from Razumkov Centre, around $1.6 \mathrm{bln}$ USD circulate in the black economy of the primary sector of the economy. It is almost $1 / 3$ of the annual state budget (Rogožyn 2004). The introduction of the free market economic relations at the beginning of the transformations increased the price disparity and in fact caused the further degradation of agriculture. Due to farmers' weakness and conservatism as well as the insufficiently developed sphere of farmers-agriculturists, the strategy of agricultural reforms is currently shaped by the 
interests of trade-financial capital.

Only in the case of immediate effective agricultural reforms and raising the living standards of rural population can it be expected that destructive demographic changes in Ukrainian rural areas will be impeded, at least to a small extent. Otherwise, as the UN predicts, over the last 50 years the population number of Ukraine will have decreased to c. $40 \%$, mainly due to the depopulation of rural areas. It will be the highest depopulation rate in the world.

\section{References}

[1] Deržavnyj komitet statistiky Ukrajiny (2008). Socjalno-ekonomične stanovyšče domogospodarstv Ukrajiny u 2006 r. (za danymy vybirkovogo obstežennia umov žyttia domogospodarstv). Retrieved May 21, 2008, from (http://www.ukrstat.gov.ua/operativ/operativ2007/gdvdg_rik/dop_sesd_2006/sesd.2006.htm).

[2] Deržavnyj komitet Ukrajiny u spravach sim'ji ta molodi. (2003). Moloda sim'ja w Ukrajini: problemy stanovlennja ta rozvytku. Tematyčna deržavna dopovid' pro stanovyšče simej v Ukrajini za pidsumkamy 2002 roku. Kyjiv.

[3] Gejc, V. (2003). Ekonomika Ukrajiny: strategija i polityka dovgostrokovogo rozvytku. Kyjiv: Vydavnyctvo Feniks.

[4] Gnybidenko, I.F., Gudzyns'kyj, C.O., Vitvic'kyj, V.V., Melnyk, S.I., Orlatyj, M.K. \& Jakuba, K.I. (2003). Trudovyj potencial sela. Kijiv: Ukrajins'ka Akademija deržavnogo upravlinnia pry Prezydentovi Ukrajiny.

[5] Laiferowa, E. (1999). Długotrwałe bezrobocie w kontekście rozwoju rynku pracy w Słowacji. Annales Universitatis Mariae Curie-Sklodowska. 24(12/l), 180-185

[6] Libanova, E.M. (2006). Liuds'kyj rozvytok v Ukrajini: možlyvosti ta napriamy socjalnych investycij. Kyjiv:,Instytut demografii ta socjalnych doslidžen' NAN Ukrajiny, Deržavnyj komitet statystyky Ukrajiny.

[7] Ministerstvo Ochorony Zdorov'ja Ukrajiny. (2000). Ochorona zdrorov'ja Ukrajiny: rezultaty dijalnosti (ščorična dopovid', 1999). Kyjiv.

[8] Narodonasielienije (1994). In Encyklopiedičeskij slovar. Moskva: Bol'šaja Rossijskaja Encyklopiedija.

[9] Naselennja Ukrajiny 1993 (1994). In Demografičnyj ščoričnyk. Kyjiv: Deržavnyj komitet statystyky Ukrajiny.

[10] Naselennja Ukrajiny 2006 (2007). In Demografičnyj ščoričnyk. Kyjiv: Deržavnyj komitet statystyky Ukrajiny.

[11] Pantylej, W. (2008). Przemiany społeczno-gospodarcze a stan zdrowia ludności Ukrainy $i$ Polski w latach 1990-2002. Lublin: Wydawnictwo Uniwersytetu Marii Curie-Skłodowskiej.

[12] Rogožyn, O.G. (2004). Demografični perspektywy ukrajins’kogo sela (istoryčni peredumovy, regionalnyj analiz i modeliuvannia. Kyjiv: Instytut problem nacionalnoji bezpeky pry Radi Nacionalnoji Bezpeky i Oborony Ukrajiny.

[13] Saluk P.G. (2002): Naselennia i trudovi resursy sela. Navčalnyj posibnyk. Kyjiv: Instytut agrarnoji ekonomiky Ukrajins'koji Akademiji Agrarnych Nauk.

[14] Ševčuk, L. T. (2003). Medyko-social'ni problemy vykorystannja trudovogo potencialu: regional'nyj analiz i prognoz. Lviv: Instytut regional'nych doslidžen'.

[15] Social'ni indykatory rivnia žyttia naselennja (2005). In Statystyčnyj zbirnyk. Kyjiv: Deržavnyj komitet statystyky Ukrajiny.

[16] Statystyčnyj ščoričnyk Ukrajiny 2006. (2007). Kyjiv: Deržavnyj komitet statystyky Ukrajiny.

[17] WHO/Europe HFA Database, November 2007. 
[18] Zastavnyj, F.D. (2003). Demografični vtraty Ukrajiny. Golodomory, vijny, emigracji. Lviv: Vydavnyčyj centr LNU im. Ivana Franka.

[19] Zatoński, W. (2001). Rozwój sytuacja zdrowotnej w Polsce na tle innych krajów Europy Środkowej i Wschodniej. Warszawa: Centrum Onkologii - Instytut im. M. CurieSkłodowskiej.

[20] Zatoński, W., Smans, M., Tyczyński, J., Boyle, P. (1996). Atlas of Cancer Mortality in Central Europe (1996). IARC Scientific Publications, Lyon: International Agency for Research on Cancer 134

[21] Žylka, N.J. (2005): Analityčnyj ogljad zakonodavčogo zabezpečennja ochorony reproduktyvnogo zdorov'ja v Ukrajini. Kyjiv: Vydavnyctvo Rajevs'kogo. 